\title{
Applying image mining to the analysis of rock structure images
}

\author{
Magdalena Habrat, Przemysław Lisowski
}

AGH University of Science and Technology, Faculty of Geology, Geophysics and Environmental Protection; al. Mickiewicza 30,30-059 Krakow, Poland; e-mail:mladniak@agh.edu.pl

(c) 2015 Authors. This is an open access publication, which can be used, distributed and reproduced in any medium according to the Creative Commons CC-BY 4.0 License requiring that the original work has been properly cited.

Obtaining, storing and sharing geological digital data in a form of images have been influenced by the dynamic development of information technology. Due to the fact that the multimedia data is not connected with a give PC or storage medium any more, but it is widely available as databases stored on network servers and accessed simultaneously by a number of users this suggests that data should be analyzed also in a new, for example parallel form. It necessitates defining the way in which the data in question is organized and interpreted efficiently.

The aim of this discussion is to present the possibility to define image mining method for understanding and analyzing large image sets based on the methods of image analysis. The Authors present the concept of IT system developed to search for the images of particular rock structures in multimedia databases. Up till now, the use of databases in the image analysis process has been reduced to storing large amounts of data in form of images. However, all transformations and the analysis of such sets are performed on the user's PC. On the one hand, this requires a large data set (images) to be sent by network each time, but on the other hand this may also pose problems resulting from managing such large amounts of analyzed images on a PC. A solution for image exploration, which is based on any attributes extracted with computer image analysis with the use of extensions for server-side operations is proposed. The proposed approach eliminates these problems completely by moving all transformations of image analysis onto a database server platform. For this purpose, a set of routines realizing transformations of image analysis and mathematical morphology were developed. The proposed approach allows the unification of the image processing and analysis area as well as advanced statistical analysis of obtained parameters describing geometrical sized of the objects and images.

The methodology is based exclusively on an image request, to which the system's response is a set of images presenting visually similar rocks ( $\mathrm{Lad}-$ niak \& Młynarczuk 2015). The search is based only on the query in the form of the image, while the system in response returns a collection of photographs representing the same structure of the rock. The proposed method is based on the methods of image analysis and the artificial intelligence, in particular, on the methods of data clustering and data classification. Decisions concerning the classification were based on six different methods of clustering and classification of data. As a result of the study showed that methods such as MEC, and based on the naive Bayes classifier and the method of the $k$-nearest neighbors have a very good classification results reaching for some of the studied rocks up to $100 \%$ correct decisions. To detect the similarity it is required to apply Determination of the characteristics identifying photographs (using image analysis algorithms), then verification of feature representativeness - to reduce considerable correlation between the measure of particular features in the representations of particular features, and apply decision making methods (in form of methods of cluster analysis). 
As a results, the proposed methodology was illustrated by practical realization of measurement types for a simple structure of copper concentrate, from the point of view of image analysis, structures such as dolomites from, for example, Rędziny and Laskowa Góra and sandstones from Tumlin and Wiśniówka and also from the point of view of method where the purpose is to enable effective search of images of a given rock in multimedia databases. The research material was microscope images of thin sections of 19 rock types. The analyzed rocks came from the southern regions of the Polish (Carpathian and Sudeten) Mountains. From these rocks thin sections were made. The photos were taken with a polarized light optical microscope, at the optimum illumination and magnification which was the same for all the photos registered for a given type of rock. For each rock type, 250 photos were taken. The collection of images that were used in the process of performing measurements encompassed 5,250 digital images presenting 21 rock types. The discussed system concept, based on a feature space defined by the authors, successfully matches up images with the reference standard. The effectiveness rate of that process is very high (very often, it is $100 \%)$. Failed classifications concern only the images which differ visually in a considerable way from the rest of the images within a given group.

As a conclusion authors would like to show that the main purpose of proposed solution is to facilitate the decision-making process involved in determining the measurements of the stereological parameters of rocks and the similarity of investigated objects. The proposed method of image mining is based on the application of database technologies, image processing, and image analysis and artificial intelligence concepts. The authors demonstrate that these may turn out to be effective mathematical methods, successfully applied to the problem of image understanding, performed with imagings presenting rock textures. In the opinion of the authors, it meets the requirements and, as such it can be applied to the problem of searching for images in databases, searching discs in order to find images of a given rocks and automatic information gain based on video sequences, e.g. in order to find frames presenting particular rock structures.

\section{REFERENCES}

Bodziony J., Konstankiewicz K. \& Pukos A., 1995. Stereology as image analysys method of agricultural materials. Agrophysics, 9, 293-309.

Ładniak M. \& Młynarczuk M., 2015. Search of visually similar microscopic rock images. Computational Geosciences, 19, 1, 127-136.

Ładniak M., Piórkowski A., \& Młynarczuk M., 2013. The data exploration system for image processing based on server-side operations. Computer Information Systems and Industrial Management, 8104, 168-176.

Mlynarczuk M., Ladniak M., \& Piorkowski A., 2014. Application of database technologies to analysis of rock structure images. Physicochemical Problems of Mineral Processing, 50, 2, 563-573.

Młynarczuk M., 2008. Zastosowanie metod analizy obrazu i morfologii matematycznej do ilościowego opisu uksztattowania powierzchni przełamów skalnych. Archives of Mining Sciences. Monografia, 3, Wydawnictwo Instytutu Mechaniki Górotworu PAN, Kraków.

Tadeusiewicz R., 2006. Data mining jako szansa na relatywnie tanie dokonywanie odkryć naukowych poprzez przekopywanie pozornie całkowicie wyeksploatowanych danych empirycznych. [in:] Wątroba J. (red.), Statystyka $i$ data mining $w$ badaniach naukowych, StatSoft Polska, Kraków, 5-30. 